\title{
Assessment of Patients Transferred from the Emergency Department to Home by Ambulance
}

\author{
(1) Hasan Sultanoğlu, (1) Mustafa Boğan, (1) Güleser Akpınar, (1) Mehmet Cihat Demir
}

Department of Emergency Medicine, School of Medicine, Düzce University, Düzce, Turkey

\begin{abstract}
Aim: Our research aimed to examine patients' sociodemographic characteristics transferred from the emergency department to home by ambulance and the factors that cause ambulance transport. To our knowledge, there is no study presenting a perspective on patients who were discharged from the emergency department but were transferred home by ambulance. Although the literature on patients using prehospital ambulance services is full, it lacks patients in need of post-hospital ambulance services. Since it is the first study on this subject, it aims to guide future studies.

Materials and Methods: This retrospective study was conducted at an academic tertiary care emergency department in Turkey between March 2019 and March 2020.

Results: Of the 1059 patients included in the study, 56.1\% were women, $43.9 \%$ were male, and their average age was 74.21 years. The most influential factors in transporting patients from the emergency department to home by ambulance were bedridden (\%47,4), social reasons(\%37,7) and oxygen need $(\% 14,9)$.

Conclusion: The high average age of patients transferred from the emergency department to the home and the reasons for their transportation demands show that the increasing elderly population creates new requirements in health. Providing ambulance service to special groups for home transport after emergency room discharge should be seen as an emergency treatment. Standardization should be developed by carrying out studies on this subject.
\end{abstract}

Keywords: Ambulance, transfer, emergency department

\section{Introduction}

Emergency services are easily accessible units that provide uninterrupted health care. In addition to medical necessity, special conditions related to the patient and his/her social situation may also play a role in emergency service admissions. In the developing health system, leaving the hospital should be scrutinized as well as the patients' arrival process. Every patient admitted to the emergency department should be carefully evaluated (1). Pre-hospital emergency health services have been established to provide both rapid treatment and critically ill patients' transport to emergency departments (2). Inter-hospital transfer rules regulated and supervised by various circulars issued by the Turkish Republic Ministry of Health maintain their importance $(3,4)$. Also, the American College of Emergency Physicians states that institutions should obey certain rules regarding "appropriate interhospital patient transfer" (5). Demand for emergency ambulance services has been increasing in recent years. The rate of demand for ambulance services for hospital admission has grown over the years. Remarkably, the need for ambulance services for transfer from the hospital to home has also recently increased. Although there are studies on transfer from the field to the hospital, there are no regulations or research regarding transferring from the hospital to home.

Our study aimed to reveal the sociodemographic characteristics of the patients who transferred home from the emergency department by ambulance and the factors that impact the 
ambulance request. This first study was also intended to provide a basis for further studies.

\section{Materials and Methods}

This retrospective, cross-sectional study was conducted at an academic tertiary care hospital emergency department in Turkey between March 2019 and March 2020. The study protocol was approved by the Düzce University Ethics Committee (decision number: 2020/41, date: 02/03/2020).

Patient information was obtained from the hospital data processing system, emergency department triage records, and forms that were prepared and required to be filled in by the hospital administration to transfer by ambulance. By examining the patients' symptoms and the International Classification of Diseases (ICD) codes at the time of admission that was accessed from the medical records, mean age, gender distribution, the way of arrival to the hospital, disease-based patient distribution, the reason for requesting an ambulance on discharge from the emergency department, transport, transfer time, and the distance (kilometers) the hospital and home were evaluated. When the reasons for the transfer from the emergency department to home by ambulance were analyzed, it was noted that they were categorized into three groups of patients: immobile or bedridden patients who need someone's care; patients who need oxygen support before applying to the emergency department; patients who had transportation problems due to social reasons such as financial impossibility, not having a private car, and not having a public bus at the time of discharge were examined in three groups.

All patients were included in the study because the file records were not missing. Patients transferred from other clinics by ambulance were not included in the study.

\section{Statistical Analysis}

The data were analyzed with IBM SPSS V23. Analysis results were presented as mean and standard deviation for quantitative data. The results were evaluated and interpreted at the 95\% confidence interval and at the significance level of $p<0.05$.

\section{Results}

A total of 2,554 patients was transferred to home by ambulance from a tertiary care university hospital in Turkey in one-year period. One thousand and fifty-nine patients (41.5\%) were transferred home from the emergency department, and 1,495 (58.5\%) from other clinics. Patients transferred from another clinic other than the emergency service were excluded. Of the 1,059 patients included in the study, $56.1 \%(n=594)$ were female and $43.9 \%(n=465)$ were male; their mean age was $74.21 \pm 13.08$ years (Table 1). Eighty-nine percent $(n=948)$ of the patients were transported to the hospital by ambulance, and 11\% $(n=111)$ presented without an ambulance. An analysis of the reasons for admission to the emergency department of the patients showed that $26.3 \%(n=278)$ of the patients had dyspnea; $14 \%(n=148)$ had abdominal pain; $7.2 \%(n=72)$ had poor overall status; and 7.1\% $(n=71)$ had seizure (Table 2). The underlying diseases of the patients who were transferred home were as follows;

\begin{tabular}{|c|c|c|}
\hline \multicolumn{2}{|l|}{ Variables } & n (\%) \\
\hline \multirow{2}{*}{ Gender } & Male & 465 (43.9) \\
\hline & Female & $594(56.1)$ \\
\hline \multirow[b]{2}{*}{$\begin{array}{l}\text { Emergency } \\
\text { department visit }\end{array}$} & By ambulance & $948(89)$ \\
\hline & By their own means & $111(11)$ \\
\hline \multicolumn{2}{|l|}{ Total, n } & $1,059(100)$ \\
\hline
\end{tabular}

Table 2. Complaints of patients at the emergency department

\begin{tabular}{|l|l|l|}
\hline \multicolumn{3}{|l|}{ Table . Complaints of patients at the emergency department } \\
\hline Complaints & $\mathbf{n}$ & $\%$ \\
\hline Chills & 7 & 0.7 \\
\hline Dyspnea & 278 & 26.3 \\
\hline Abdominal pain & 148 & 14.0 \\
\hline PEG problem & 66 & 6.2 \\
\hline Epileptic seizures & 71 & 6.7 \\
\hline Trauma & 25 & 2.4 \\
\hline Dysuria & 7 & 0.7 \\
\hline Cough & 21 & 2.0 \\
\hline Fever & 40 & 3.8 \\
\hline Hematuria & 21 & 2.0 \\
\hline Headache & 33 & 3.1 \\
\hline Poor overall status & 72 & 6.8 \\
\hline Nausea/vomiting & 47 & 4.4 \\
\hline Clouding of consciousness & 45 & 4.2 \\
\hline GIS bleeding & 32 & 3.0 \\
\hline General pain & 50 & 4.7 \\
\hline Incontinence & 25 & 2.4 \\
\hline Tachycardia & 14 & 1.3 \\
\hline Chest pain & 20 & 1.9 \\
\hline Lumbago & 7 & 0.7 \\
\hline Agitation & 18 & 1.7 \\
\hline Syncope & 12 & 1.1 \\
\hline Total & 1,059 & 100,0 \\
\hline n: Number of the cases, \\
Gastrointestinal system & & gastrostomy, GIS: \\
\hline & & \\
\hline
\end{tabular}


cerebrovascular accident (CVA) in 37.4\% ( $\mathrm{n}=396)$, malignancy in $14.2 \%(n=152)$, Chronic Obstructive Pulmonary Disease (COPD) in $11 \%(n=116)$, and Alzheimer's disease in 5.4\% $(n=57)$ (Table 3). The reason for home transport from the emergency department by ambulance was being bedridden in $47.4 \%(n=502)$ patients, social reasons in $37.7 \%(n=399)$, and the need for oxygen support in $14.9 \%(n=158)$ (Table 4). Of the patients who were admitted to the emergency department, $96.8 \%(n=1025)$ were transported in company with an attendant while $3.2 \%(n=34)$ of the patients were transported alone. Forty-two percent $(n=4,449)$ of the patients were transferred between 08:00 and 16:00; 39.9\% $(n=423)$ between 04:00 p.m. and 12:00 a.m.; and 17.7\% $(n=187)$ between 12:00 a.m. and 08:00 a.m. The mean transport distance was $15.9 \pm 10.1$ kilometers $(\mathrm{km})(\min -\max : 5.3-49.9 \mathrm{~km})$, and the mean transfer time was 51.6 \pm 29.7 minutes $(\mathrm{min})$ (min-max: 10$150 \mathrm{~min})$.

\begin{tabular}{|l|l|l|}
\hline \multicolumn{4}{|l|}{ Table 3. Chronic diseases of patients } \\
\hline Disease & $\mathbf{n}$ & $\%$ \\
\hline CVA & 396 & 37.4 \\
\hline COPD & 116 & 11.0 \\
\hline Lung Ca & 60 & 5.7 \\
\hline Alzheimer & 57 & 5.4 \\
\hline CAD & 49 & 4.6 \\
\hline Hip fracture & 42 & 4.0 \\
\hline Pancreatic Ca & 33 & 3.1 \\
\hline Diabetes mellitus & 32 & 3.0 \\
\hline Stomach Ca & 20 & 1.9 \\
\hline Epilepsy & 20 & 1.9 \\
\hline HT & 20 & 1.9 \\
\hline CHF & 19 & 1.8 \\
\hline Other & 125 & 13.4 \\
\hline Healthy & 52 & 4.9 \\
\hline CVA: Cerbrascular| & \\
\hline
\end{tabular}

CVA: Cerebrovascular accident, COPD: Chronic obstructive pulmonary disease, $\mathrm{Ca}$ : Cancer, CAD: Coronary artery disease, HT: Hypertension, CHF: Congestive heart failure

Table 4. Factors causing the transfer of patients from the emergency department to home by ambulance

\begin{tabular}{|l|l|l|}
\hline Transfer request reason factors & $\mathbf{n}$ & \% \\
\hline Bedridden & 502 & 47.4 \\
\hline Social reasons & 399 & 37.7 \\
\hline Need for oxygen support & 158 & 14.9 \\
\hline Total & 1,059 & 100.0 \\
\hline n: Number of the cases & \\
\hline
\end{tabular}

\section{Discussion}

The providing ambulance services in developed or developing countries and the ambulance usage rates of communities vary depending on local, socioeconomic, and cultural conditions. Emergency ambulance services worldwide are provided uninterruptedly for 24 hours under command-and-control centers at the provincial or regional scale (6).

As a result of an expansion in the elderly population, there has been an increase in the admissions of elderly patients to the emergency department (7). A study examining the age-based distribution of patients transported from the field by ambulance found that $13 \%-47.9 \%$ of patients were over 60 years of age (8). In another study examining geriatric patients admitted to the emergency department, patients who were taken under observation for follow-up and treatment purposes had a mean age of 77.8 years (9). In the literature, the male patients have a higher proportion in the gender- and age-based patient distribution, while the number of female patients exceeded the number of male patients only in the patient group over the age of 65 (10). Like the literature, our study found the mean age of 74.2 years and the female portion of $56.1 \%$ among the transferred patients.

A study showed that patients frequently present to the emergency department with respiratory system-related complaints (9). In line with previous reports, our study found that the most common admission complaint was dyspnea. In our research, the most common emergency department admission complaints in descending order after dyspnea were abdominal pain, poor overall status, and seizure. In the literature, patients who were transported to the emergency department by ambulance mostly had a provisional diagnosis of trauma, while elderly patients were most commonly transported with cardiovascular system diseases (8,10-12). In our study, the patients transferred home had CVA (37.4\%), malignancy (14.2\%), and COPD (11\%). As most patients who request home transport by ambulance are bedridden due to a history of CVA, our CVA rate was high.

When we examine the reasons for transferring patients from the emergency department to home by ambulance, $47.4 \%$ was due to being bedridden, $37.7 \%$ to social causes, and $14.9 \%$ to oxygen need. There are no studies in the literature on patients transferred home from the emergency department by ambulance to the best of our knowledge.

In a study on ambulance services in Ireland, $81 \%$ of the patients were transported from the scene to the hospital in under 15 minutes (13), while the average time was found to be 8.2 minutes in the United States of America (14). In our study, the meantime 
of home transport from the hospital was 51.6 minutes, and the mean transport distance was $15.9 \mathrm{~km}$. No comparison could be made due to the lack of similar studies in the literature on home transport from the hospital; however, the transport time and distance may have been increased by an unknown destination and insufficient supporting personnel in transport ambulances.

In the literature studies, $53.6 \%$ of patients were admitted to the emergency department between 04:00 p.m. and 08:00 a.m. (12), and a decrease in the number of patients presenting both by ambulance and as an outpatient between 12:00 a.m. and 07:59 a.m. was reported (15). In our study, $42 \%$ of the patients admitted to the emergency department between 08:00 a.m. and 04:00 p.m.; 39.9\% between 04:00 p.m. and 12:00 a.m.; and 17.7\% between 12:00 a.m. and 08:00 a.m.. These findings are consistent with the results reported by researches on hospital admission by ambulance.

\section{Conclusion}

With the prolongation of human life, the number of elderly patients admitted to the emergency department is also increasing. However, patients demanding an ambulance for home transfer from the hospital increased. Providing ambulance service to special groups to reach home after discharge in the emergency department should be seen as a part of emergency treatment. To standardize patient transfers from hospital to home by ambulance, proper indications should be determined by regulations, and studies involving interdisciplinary cooperation should be carried out.

\section{Ethics}

Ethics Committee Approval: This retrospective clinical study was approved by the Local Ethics Committee of Düzce University Faculty of Medicine (decision number: 2020/41, date: 02/03/2020).

Informed Consent: Retrospective study.

Peer-review: Externally peer-reviewed.

\section{Authorship Contributions}

Surgical and/or Medical Practices: H.S., Concept: M.B, M.C.D., Design: H.S., G.A., Data Collection and/or Processing: H.S., M.B., G.A., M.C.D., Analysis and/or Interpretation: H.S., G.A., M.C.D., Literature Search: H.S., M.B., Writing: H.S.
Conflict of Interest: No conflict of interest was declared by the authors.

Financial Disclosure: The authors declared that this study received no financial support.

\section{References}

1. Morgans A, Burgess S. Judging a patient's decision to seek emergency healthcare: clues for managing increasing patient demand. Aust Health Rev. 2012;36:110-4

2. Knapp BJ, Kerns BL, Riley I, Powers J. EMS-initiated refusal of transport: the current state of affairs. J Emerg Med. 2009;36:157-61.

3. Acil Hasta Sevkleri ile ilgili 2006/110 sayılı Sağlık Bakanlığı Genelgesi. Sağlık Bakanlığı internet sitesi. (Erişim tarihi: 5 Aralık 2020) Adres: http://www.saglik.gov.tr/TR/Genel/DosyaGoster.aspx?BELGEANAH=153 85\&DIL=1\&DOSYAISIM=acil_hasta_sevkleri.doc

4. Acil Sağlık Hizmetlerinin Sunumu ile İlgili 2008/13 Sayılı Başbakanlık Genelgesi. Resmi Gazete internet sitesi. (Erișim tarihi: 5 Aralık 2020) Adres: http://rega.basbakanlik.gov.tr/eskiler/2008/06/20080626.htm

5. American College of Emergency Physicians. Emergency Medicine Practice Committee. Appropriate inter hospital patient transfer. AnnEmergMed 2002 ;40: 544-5.

6. Sofuoğlu T. Dünya'da Ambulans Servislerinin Gelișimi. III. Ambulans Rallisi ve Acil Sağlık Hizmetleri Kongre Kitabı: 14-16, 22-26 Ekim 2007 Ankara.

7. Çilingiroğlu N, Demirel S. Yașlılık ve yașlı ayrımcılığı. Türk Geriatri Dergisi. 2004;7:225-30

8. Yurteri H, Saran A, Özgün İ. Hızır acil ambulanslarıyla alınan vakaların değerlendirilmesi. Ulus Travma Acil Cerrahi Dergisi. 1996;2:204-7.

9. Varıșlı B, Doğan FS, Yiğitbaș MR. Acil Servise Bașvuran Geriatrik Yaș Grubu Hastaların Klinik, Demografik ve Maliyet Açısından İncelenmesi. Anatolian Journal of Emergency Medicine. 2018;1:18-24.

10. Zenginol M, Al B, Genç S, Deveci İ, Yarbil P, Yilmaz DA, et al. 3 Yearly Study Results of 112 Emergency Ambulances in the City of Gaziantep. Eurasian Journal of Emergency Medicine. 2011;10:27.

11. Unsal A, Ayranci U, Cevik AA, Metintas S, Arslantas D, Unluoglu I. Use of emergency departments by elderly patients in a city of Western Turkey. European Journal of Emergency Medicine. 2007;1:125-9.

12. Bedel C, Tomruk Ö. Bir Üniversite Acil Servisine Bașvuran Geriatrik Hastaların Özellikleri. SDÜ Tıp Fakültesi Dergisi. 2018;4:393-9.

13. Breen N, Woods J, Bury G, Murphy AW, Brazier H. A national census of ambulance response times to emergency calls in Ireland. J Accid Emerg Med. 2000;17:392-5.

14. Campbell JP, Gridley TS, Muelleman RL. Measuring response intervals in a system with a 911 primary and an emergency medical services secondary public safety answering point. Ann Emerg Med. 1997;29:492-6.

15. Seow E, Wong HP, Phe A. The pattern of ambulance arrivals in the emergency department of an acute care hospital in Singapore. Emerg Med J. 2001;18:297-9 